\title{
The Politics of Gay and Lesbian Rights: Expanding the Scope of the Conflict
}

\author{
Donald P. Haider-Markel \\ Kenneth J. Meier \\ University of Wisconsin-Milwaukee
}

\begin{abstract}
Morality politics theory predicts that gay rights policy will reflect the influence of religious groups, party competition, and partisanship while interest group theory suggests that these policies will correspond with interest group resources, elite values, and past policy actions. Using multiple regression on a 50-state data set and a county-level data set for gay rights initiatives in Oregon and Colorado, we found gay and lesbian politics are no different from those for other policy issues. When gay and lesbian rights are not salient, the pattern of politics resembles that of interest group politics. If individuals opposed to gay and lesbian rights are able to expand the scope of the conflict, the pattern of politics conforms to morality politics.
\end{abstract}

A

Ithough the gay rights movement predates the 1969 Stonewall riots, mainstream political science scholarship has generally ignored gay and lesbian politics. Salient political issues such as military service, AIDS funding, hate crimes, or antidiscrimination policies have received only journalistic analysis. Such a void is surprising since gay and lesbian politics at least superficially fits the pattern established for other morality politics issues such as alcohol, abortion, drugs, and gambling. The politics of these highly salient issues generally involves two competing coalitions often formed around religious beliefs and/or partisanship. The process resembles that of redistributive politics except groups seek to redistribute values (not income) by having government put its stamp of approval or disapproval on a specified set of values (see Gusfield 1963; Goggin 1993; Meier 1994).

This research integrates the study of gay and lesbian politics into political science by assessing the politics of state and local policies protecting gays and lesbians from discrimination in several areas. First, the literature on morality politics will be reviewed to specify a general model that appears to fit gay and lesbian politics. Second, an alternative model based on interest group interaction with political

An earlier version of this article was presented at the 1995 annual meeting of the Midwest Political Science Association. We would like to thank Lee Sigelman, Kevin B. Smith, Brett Hawkins, Susan Burgess, Greg Lewis, and Thomas Holbrook for comments on earlier drafts. The data and documentation necessary to replicate this analysis are available in a file under the authors' names from the State Politics and Policy Data Archive, Policy Sciences Center, Florida State University.

The Journal of Politics, Vol. 58, No. 2, May 1996, Pp. 332-49

(C) 1996 by the University of Texas Press, P.O. Box 7819, Austin, TX 78713-7819 
elites is outlined, suggesting that the narrower scope of conflict in interest group politics advantages one set of participants. These two models are tested twiceonce based on a 50-state study of state and local policies that protect the rights of gays and lesbians in seven areas and once based on county returns for 1992 initiatives in Oregon and Colorado. We conclude that in general gay and lesbian politics resembles interest group politics where interest groups interact with sympathetic political elites; but, when groups opposed to gay and lesbian rights are able to expand the scope of the conflict to electoral politics (through initiatives), then the pattern of politics changes to one of traditional morality politics.

\section{Morality Politics}

Moral disputes over values have a long political history in the United States. Although such disputes have a highly symbolic edge to them because many morality policies are rarely enforced, Gusfield (1963) argues that these disputes should be seen as attempts to redistribute values, to put the government's stamp of approval on one set of values rather than another. Gusfield presents his argument in the context of alcohol prohibition; he portrays prohibition as an attempt by rural, Protestant, native-born citizens to establish the superiority of their values over those of urban, Catholic immigrants. Morality policy, thus, is similar to redistributive policy; but the redistributed good is not money or government programs but values.

The pattern of morality politics has been identified in abortion politics (Luker 1984; Goggin 1993), drug and alcohol policies (Gusfield 1963; Meier 1994), sodomy laws (Nice 1988), and gambling (Morgan and Meier 1980), and is also probably present in issues such as prostitution enforcement, Sunday closing laws, birth control, and the recent concern with family values. In each case at least one advocacy coalition (Sabatier 1988) involved has portrayed the issue as one of morality or sin and used moral arguments in its policy advocacy. Gay and lesbian rights appears to fit this pattern. Although most gay and lesbian organizations seek to portray their objectives as civil rights issues rather than as morality issues, ${ }^{1}$ their opponents frame these issues as moral issues and frequently cite biblical literature and its prohibitions against homosexuality.

The research literature finds that morality politics issues are highly salient with little need to acquire any information (technical or otherwise) to participate in the debate. Everyone is an expert on morality. The combination of high salience and low information structures the nature of the politics involved (see Gormley 1986;

\footnotetext{
'Gays and lesbians are an extremely diverse population, and most generalizations are likely to be false simply because only open gays and lesbians are visible actors on these issues. Open gays have lower incomes, are younger, and have lower-status occupations than nonopen gays (Harry 1993, 34). Based on other research on interest groups (Luttbeg and Zeigler 1966; Sabatier and McLaughlin 1990), we hypothesize that open gays and lesbians are likely to be stronger advocates of gay rights and less conservative than their closeted colleagues. Some gays, therefore, might see gay rights as a moral issue.
} 
Lowi 1969; similar to easy issues in Carmines and Stimson's 1980 terminology). Citizens, therefore, are active and influential in morality politics with coalitions often mobilized around preexisting religious beliefs. Politicians and political parties find morality issues attractive because the issues offer an easy way to build a political reputation or stereotype one's opponents. Politicians face no information barriers to participate (as in other policy areas such as health insurance reform) and can potentially accrue great benefits from the mobilized electorate. Because disputes are over deeply held values, compromise solutions rarely attract any support. Morality politics, therefore, like redistributive politics tends to be partisan, seek nonincremental solutions, focus on deeply held values, and flourish in areas with competitive political parties (Ripley and Franklin 1991; Lowi 1969).

Bureaucratic institutions cannot bring their prime resource-information-to bear on such policies and, therefore, are generally not influential in morality politics. Interest groups are active but are thrown directly into conflict with mobilized citizens and politicians. Interest groups generally fare best when they limit the scope of the conflict and discretely lobby policymakers for favorable public policy (Browne 1988; Lowi 1969; Schattschneider 1960). As the scope of the conflict broadens, the relative advantages of interest groups (i.e., access and special knowledge) become less important in influencing policy.

A morality model of politics, therefore, predicts that the most important variables in explaining public policy are the distribution of citizen values, the competitiveness of parties, and the party affiliations of politicians. In this situation interest groups' influence will be less important.

Although gay and lesbian rights policies seem ready made for morality politics, this compatibility assumes that individual actors will passively let politics take its course. As Schattschneider (1960) so eloquently argued, an effective strategy of interests is to limit or expand the scope of the conflict so that their position gains an advantage. Although the number of gays and lesbians is a hotly disputed figure, the highest estimate is only $10 \%$ of the population. Clearly any group representing a minority this small knows that without generating sympathetic support from the straight community, it will remain a minority in the highly politicized public disputes that characterize morality politics. A better option would be the time-tested interest group tactic of discrete lobbying of sympathetic policymakers. A common approach would be for an interest group to argue to its allies in policy-making positions that the policy proposal is merely an incremental change from current policy. If the scope of the conflict can be limited, then such decisions can be made in relative obscurity. A policymaker in this situation might well see an intense minority seeking a policy in a situation with a quiescent majority, in short, as day-to-day interest group politics. If the scope of the conflict can be limited, therefore, the interest group model suggests that the important variables in predicting policy outputs are interest group resources, the values of political elites, and the normal incremental process of politics. 


\section{An EMPIRICAL Test}

\section{Dependent Variables: Public Policy}

Our first analysis examines public policies that prohibit discrimination on the basis of sexual orientation. Using U.S. states as the units of analysis, seven policy areas are included-prohibitions against discrimination in public employment, public accommodations, private employment, education, housing, credit, and union practices. These categories mirror antidiscrimination policies previously sought by minorities and are the target areas chosen by the oldest gay and lesbian lobbying organization in the United States, the National Gay and Lesbian Task Force, or NGLTF (see National Gay and Lesbian Task Force Policy Institute 1993). ${ }^{2}$

Each indicator for the seven policy areas was measured in the same way (the sources and years for all data are listed in the appendix). We determined the jurisdiction covered by each policy in a state (whether it be a state, county, or city policy), summed the population of these jurisdictions, and calculated the percentage of the state's population covered by the law. ${ }^{3}$ For example, while Arizona does not have a state law prohibiting discrimination in public employment, its two largest cities do (Phoenix and Tucson). Based on the population of those two cities as a percentage of the total state population, $37.9 \%$ of the state's population is covered by laws prohibiting discrimination in public employment based on sexual orientation.

Our measurement of antidiscrimination policies, by combining state and local policies, is more precise than most measures of policy used in state level analysis. Because only 140 such policies exist nationwide and only nineteen states have state-level laws, the exclusion of county and city policies would not provide a realistic view of existing antidiscrimination policy (NGLTF Policy Institute 1993). States with a substantial proportion of the population covered by local policies also may not perceive a need to pass additional legislation. ${ }^{4}$

The measure has reasonable face validity. The seven measures, while tapping

\footnotetext{
${ }^{2}$ For a more in-depth discussion of issues concerning gays, lesbians, and their interest groups see Blasius (1994), Cohan (1982), D'Emilio (1983), and Gonsiorek and Weinrich (1991).

${ }^{3}$ We attempted to avoid double counting in our estimates; that is, cities within a county that had a similar law were counted within the population of the county only, not as a separate population. The wording of policies could become important in cases such as these, but we were able to find only slight variation in wording and applicability. Although Colorado's state laws were repealed by initiative in 1992 , it was included in the data set because the initiative was enjoined by a state court and voided by the Colorado Supreme Court. Any city repeals after May 1993 were not included; several were pending. For an alternative method of aggregating these policies, see Wald, Button, and Rienzo (1996).

+ The state versus local forums means that the argument about expanding the scope of the conflict also has a spatial dimension. Groups can seek policies or repeal of policies in jurisdictions that may be more supportive of their views. Using states as the units of analysis has the advantage of expanding the range of the dependent variable. It also suggests that groups with less resources will try to change policies in smaller jurisdictions rather than state wide. Our measure is sensitive to such variations.
} 
separate policy categories, are highly correlated. A factor analysis of the seven measures results in a single significant factor accounting for $81 \%$ of the total variation. Accordingly we will analyze the antidiscrimination policies both as a summed measure across all seven policies and as individual policy areas.

\section{Independent Variables: The Interest Group Model}

Interest groups are a key element in public policy when the policy process conforms to lobbying politics but are less influential in morality politics. Although the National Gay and Lesbian Task Force and the Lambda Legal Defense and Education Fund are two of the most active gay/lesbian groups in the United States (see Cohan 1982), local groups also have considerable strength (see Gibson 1987). ${ }^{5}$ Because we are using states as the unit of analysis, we restrict our interest group measures to those that can be measured at the state level for all states. Our interest group membership variable is simply the number of NGLTF members per 100,000 population in the state. ${ }^{6}$

Membership is only one potential interest group resource; another is money. Money permits groups to lobby legislators, gear up letter-writing campaigns, coordinate supporters, hire people who have political expertise, and countless other things. While numbers per se are useful, raw membership totals do not necessarily reflect the other resources a group can use to influence policy. Our measure of resources is the average dollar contribution per member made by Task Force members.

Ideally a study such as this one would include a measure of gay and lesbian population. Population is, of course, a potential political resource. No such measure exists, however. Membership in the Task Force or Lambda reflects openly gay population more than it reflects the total gay population. As an attempt to provide a general resource measure for the gay community, we coded the number of gay bars, gay businesses, and gay newspapers per 1 million population in the state. While this measure is also probably more sensitive to the openly gay population, it provides another indicator of potential resources.

Litigation has been a major tactic of interest groups in antidiscrimination policy, and Lambda seeks to emulate the successes of the NAACP and other civil rights litigation organizations (see Stewart and Sheffield 1987). We measured Lambda litigation as the number of successful cases Lambda participated in from the winter of 1976 to the winter of $1994 .^{7}$ Our count included the number of amicus briefs,

\footnotetext{
5Our impression is that membership in national gay and lesbian groups overlaps local groups' membership a great deal. Interviews revealed that the national organizations generally provide advice and technical assistance while local groups provide the legwork in effor ts to obtain protective policies.

${ }^{6}$ We did not also use Lambda membership because the measures correlate at .87 , far too collinear to use in the same equation.

'This variable was constructed by tracking cases through The Lambda Update. Cases were counted when Lambda determined that further appeals were either not possible at the state level or that all concerned parties would not seek further appeals. If a case moved from the state courts into the federal court system, it was tracked as a new case and counted in the same manner. Cases that Lambda started but were eventually dropped by the plaintiff were not counted.
} 
test cases (as counsel or co-counsel), and federal appeals per 100,000 state population where the final outcome was favorable. While other groups such as the American Civil Liberties Union have recently become active in gay and lesbian litigation, Lambda has established itself as the leading litigation group in the area.

If gay/lesbian policy is formed within the more closed arena of interest group politics, the political values of political elites become crucial. If political elites hold values sympathetic to gay and lesbian rights, they are more likely to support such policies in the policy process. To measure elite support for gay and lesbian rights, we used a set of key congressional votes and averaged the vote scores for the entire state delegation. The specific roll calls were those designated as significant gay and lesbian issues by the National Gay and Lesbian Task Force; the measure was calculated for the One-hundredth, One-hundred first, and One-hundred second Congresses. ${ }^{8}$ Such an indicator assumes that state political elites hold values that are reasonably consistent with the values expressed by the votes of members of Congress from their states. Similar measures have been used successfully in tapping general political ideology (Holbrook-Provow and Poe 1987), support for consumer protection (Meier 1987), and support for environmental protection (Ringquist 1993).

To avoid attracting the attention of other political actors, interest group politics is almost always incremental in nature. As a result, past policies provide guidelines for elites in dealing with interest groups. Gay and lesbian organizations attempt to portray antidiscrimination policies as civil rights issues rather than morality issues. State elites might use past activity in passing antidiscrimination laws to protect other people as cues to establish new policies for gays and lesbians (see Holbrook and Percy 1992, 209-10, on disability protections; Savage 1978; Hofferbert and Urice 1985). States passing antidiscrimination laws for blacks before the federal government made its major effort in 1964, for example, have a strong civil rights tradition and, therefore, may be more likely to consider similar policies for other groups. We include, as our measure of policy history, the McCrone and Cnudde (1968) additive index of state antidiscrimination laws passed to protect blacks before 1964 .

\section{Independent Variables: The Morality Politics Model}

Morality politics, in contrast to interest group politics, involves open conflict between advocacy coalitions with different concepts of values and morality. Because religious groups have explicit moral codes, they are frequently significant players in morality politics. Religious groups may influence public policy either

\footnotetext{
${ }^{8}$ This information was obtained from the NGLTF Policy Institute and involves issues such as AIDS funding, a national gay civil rights bill, immigration policy, etc. NGLTF develops report cards for each member of Congress by determining the percentage of favorable votes cast by the member for the NGLTF position. Each session's ratings are based on approximately 10 roll calls. An alternative measure might have been the percentage of openly gay elected officials, but only 75 people were known to fit this category before 1994 (Morrison 1992, 2682).
} 
indirectly through public opinion or directly by attempting to influence policy. The religious organizations likely to have the largest influence are Catholics and Protestant Fundamentalists because their religious doctrines are in conflict with gay behavior (see Nice 1988; Seltzer 1993, 93).

Because Sniderman et al. $(1991,48)$ found a significant relationship between negative feelings toward homosexuals and opposition to the civil liberties of homosexuals, one might expect that people belonging to groups that frown upon homosexual behavior would be less likely to support gay rights. Although our discussion indicates that both Catholics and Protestant Fundamentalists would oppose civil rights for gays and lesbians, Catholics may be a special case. Nice $(1988,205)$ found that while official Catholic doctrine is clearly against homosexual behavior, Catholics in the United States appear to be more tolerant of homosexuals and more lenient in their attitudes toward private sexual relations. Other recent research confirms a majority of committed Catholics favor gay rights (Woodward 1993, 81). Similar to past research (Gusfield 1963; Nice 1988; Meier 1994), our measures are the percentages of state population that belongs to Catholic churches and the percentage that belong to Protestant Fundamentalist denominations. ${ }^{9}$

Morality politics also responds to political forces (Meier 1994; Nice 1988). When morality politics evolves into a redistributive policy process whereby the government policy sanctions one set of values rather than another (Gusfield, 1963; Ripley and Franklin 1991), the key dispute becomes whose values will have official government sanction. In such circumstances elected officials are drawn into the conflict; and partisanship, electoral competition, and salience become important forces.

Politicians and political parties are more likely to be open to citizen inputs and demands when electoral competition is high (Holbrook and Van Dunk 1993, 955). Competitive party systems have long been theoretically linked to liberal policies that benefit the "have nots" (Key 1964); by analogy competitive party systems should be more supportive of gay and lesbian rights. ${ }^{10}$ Rather than the usual folded Ranney index of party competition, we use the Holbrook and Van Dunk (1993) measure based on the competitiveness of individual legislative districts. ${ }^{11}$

Partisanship is also linked to some morality politics. The Republican party with its emphasis on traditional family values is often interpreted as antigay. With the more liberal orientation of the Democratic party, state legislatures that are con-

"Denominations classified as Protestant Fundamentalist were Churches of God, Latter Day Saints, Churches of Christ, Church of the Nazarene, Mennonites, Conservative Baptist Association, Missouri Synod Lutherans, Pentecostal Free Will Baptists, Pentecostal Holiness, the Salvation Army, SeventhDay Advent ists, Southern Baptists, and Wisconsin Synod Lutherans.

${ }^{10} \mathrm{Colby}$ and Baker (1988), however, argue that competitive parties increase the risk for a politician to support a controversial position.

"Holbrook and Van Dunk do not provide an estimate for Louisiana. Based on comparisons with other measures of competition and partisanship, we estimated Louisiana's score on the Holbrook and Van Dunk measure as 17.07. 
trolled by Democrats are more likely to develop liberal policies (Holbrook and Percy 1992, 299). Our measure is the percentage of Democrats in the state legislature for 1990.

A key distinction between interest group politics and morality politics involves salience. Salient issues generally receive a broader public hearing, have more active participation by citizens, attract the interest of politicians, and in short, look like normal redistributive politics (Gormley 1986, 599-600; Ripley and Franklin 1991). Salience can also be a factor in placing an issue on the agenda. Because salience in our view determines the scope of the conflict and thus quite likely the outcome of policy disputes, we include a measure of salience for issues concerning gays and lesbians. Issue salience is measured as the number of articles on gays and lesbians per 100,000 population that appear for each state between 1985 and 1993 on the Nemsbank Electronic Information System. Similar measures of salience have been used in both alcohol policy (Meier 1994) and drug policies (Becker 1963; Himmelstein 1983).

In addition to citizen and political forces, the policy environment plays a role in morality politics. These factors structure the political process in the state and provide advantages and disadvantages to various coalitions. Such forces as urbanism and region are related not only to morality politics (Meier 1994; Nice 1988) but also to other policies (Hofferbert and Urice 1985; Thomas and Hrebenar 1992). This study will include two environmental policy variables-urbanism and general levels of education. ${ }^{12}$

Urbanism is frequently included in studies of morality politics because people living in urban areas are exposed to more diverse life-styles and, therefore, are more likely to be tolerant of those life-styles (Hofferbert and Urice 1985; Meier 1994; Nice 1988). Although included as a measure of tolerance, urbanism might also indicate a larger gay population (Wilson 1995). Openly gay and lesbian populations are generally associated with urban areas. ${ }^{13}$ Our measure is the percentage of the state population living in urban areas.

Finally, if gay and lesbian civil rights policies reflect generally tolerant attitudes, we should expect that education might play a role. A wealth of studies have found that increased levels of education are positively associated with greater levels of tolerance for individuals different from oneself (Seltzer 1993, 93; Gibson 1987; Sullivan, Piereson, and Marcus 1982). Education might affect policy by making either elites or masses (or both) more tolerant. Our measure of education is the percentage of the state population with college degrees.

\footnotetext{
12 We initially included a dummy variable for the South, but it was not related to the antidiscrimination policies.

${ }^{13}$ The popular literature suggests that gays and lesbians feel more comfortable in urban areas, thus making them more likely to be "out." Some argue that only when gays and lesbians are out and have the ability to recognize each other can they mobilize politically (see Blasius 1994; Cohan 1982). Without contact, interest groups will remain latent.
} 


\section{Strategy of Analysis}

We have specified two general models of public policy likely to explain antidiscrimination policies regarding gays and lesbians. If gays and lesbians are able to limit the scope of the conflict, then we should see relationships that support an interest group model of public policy. In that case important independent variables should be measures of gay and lesbian interest group activity, elite political support, past public policies, and possibly education (if it works through political elites). If coalitions opposing gay and lesbian rights are able to expand the scope of the conflict, then the patterns should reflect morality politics. In that model the important independent variables should be religious groups, salience, urbanism, partisanship, party competition, and perhaps education (if it works through mass attitudes) with lesser impacts from the gay and lesbian interest group measures. We will estimate an equation with all independent variables from both models. Since many of the variables are somewhat collinear and since we wish to present as parsimonious a model as possible, we will then remove variables that lack explanatory power. At the same time we will examine the common regression diagnostics to determine if individual cases might be distorting our analysis and include any corrective measures. Rather than presenting the initial models, the reduced models, and the diagnostic corrected models, we will present only the final models. ${ }^{14}$

Since the dependent variable is skewed as are many of the independent variables, all variables except the civil rights measure (which is a simple count) were subjected to a log transformation. A second advantage of the log transformation is that preliminary analysis revealed that the relationships between the variables were not linear but rather were better described by $\log$ curves. The log transformation also provides an assist in interpreting the equations since the regression coefficients can now be interpreted as elasticities (see Tufte 1979).

\section{FINDINGS}

The results of our analysis for the combined measure of gay and lesbian rights policies are shown in table 1 . Without question the pattern fits that of interest group politics and is inconsistent with morality politics. Gay and lesbian rights

\footnotetext{
${ }^{14}$ We used the studentized residuals, Cook's $D$, and the hat diagonals to identify points that were deviant and likely to overly influence the regression line. With a small number of data points, regression is quite susceptible to undue influence by one or more data points (Hamilton 1992). As an alternative to our strategy for generating parsimonious models, three others exist. One is to make some theoretical assumptions in order to reduce the number of variables a priori. Since gay rights policy has not been studied empirically, we were hesitant to do this. With the publication of this study, such modeling efforts are now possible. The second strategy is to rely solely on statistical criteria such as minimizing the Schwarz Bayesian Criterion with a series of models being tested. This is a perfectly reasonable approach to model building, but does not, in our mind, pay sufficient attention to the small number of cases in our data sets and the likelihood of distorting results. The third approach is to use an iterative search procedure accompanied by bootstrapping methods of estimation.
} 
TABLE 1

Determinants of Gay/Lesbian Rights: All Seven Areas

\begin{tabular}{lrc}
\hline Independent Variable & Slope & t-score \\
\hline Interest Group Factors & & \\
Gay Task Force members & 1.11 & $3.15^{*}$ \\
Task force wealth & 1.92 & $2.21^{*}$ \\
Elite support & 2.50 & $3.56^{*}$ \\
Early civil rights support & .28 & $2.00^{*}$ \\
Environmental Factors & & \\
College graduates & 2.60 & $2.11^{*}$ \\
Unit Effects & & \\
Wisconsin & 3.07 & $2.53^{*}$ \\
Louisiana & 3.87 & $3.20^{*}$ \\
Delaware & -4.49 & $3.56^{*}$ \\
$R$-square & .82 & \\
Adjusted $R$-square & .78 & \\
Standard error & 1.17 & \\
$F$ & 23.05 & \\
Joint $f$-test excluded morality variables & .34 & \\
Probability of $F$ & .91 & \\
$N$ of cases & 50 & \\
\hline
\end{tabular}

$* p<.05$.

policies are significantly and positively related to Task Force members, Task Force resources, elite support, early civil rights policies, and high levels of education. Of these variables, only the education variable might be interpreted as a morality politics influence. Except for civil rights support, the regression coefficients may be interpreted as the percent increase in gay and lesbian rights policy coverage for a $1 \%$ increase in the independent variable, all other things being equal. Three state specific effects were identified: Wisconsin and Louisiana have much more pro-gay and lesbian policies than predicted while Delaware is much less supportive.

Not only does the model explain $82 \%$ of the variance with factors that are clearly interest group forces, but the morality variables matter little. As a second test, the morality variables were added to this equation, the joint $f$-test for the significance of these variables was .34 with a probability of .91 . In short, the morality politics variables add no additional explanation to the model.

To confirm our general findings, we then examined each of the seven policy areas separately to see if the pattern of interest group politics fit all areas. The results are shown in table 2 . As would be expected with seven different dependent variables, the results vary somewhat. The general pattern, however, holds. Task Force membership, elite support, and past civil rights policies are significant 


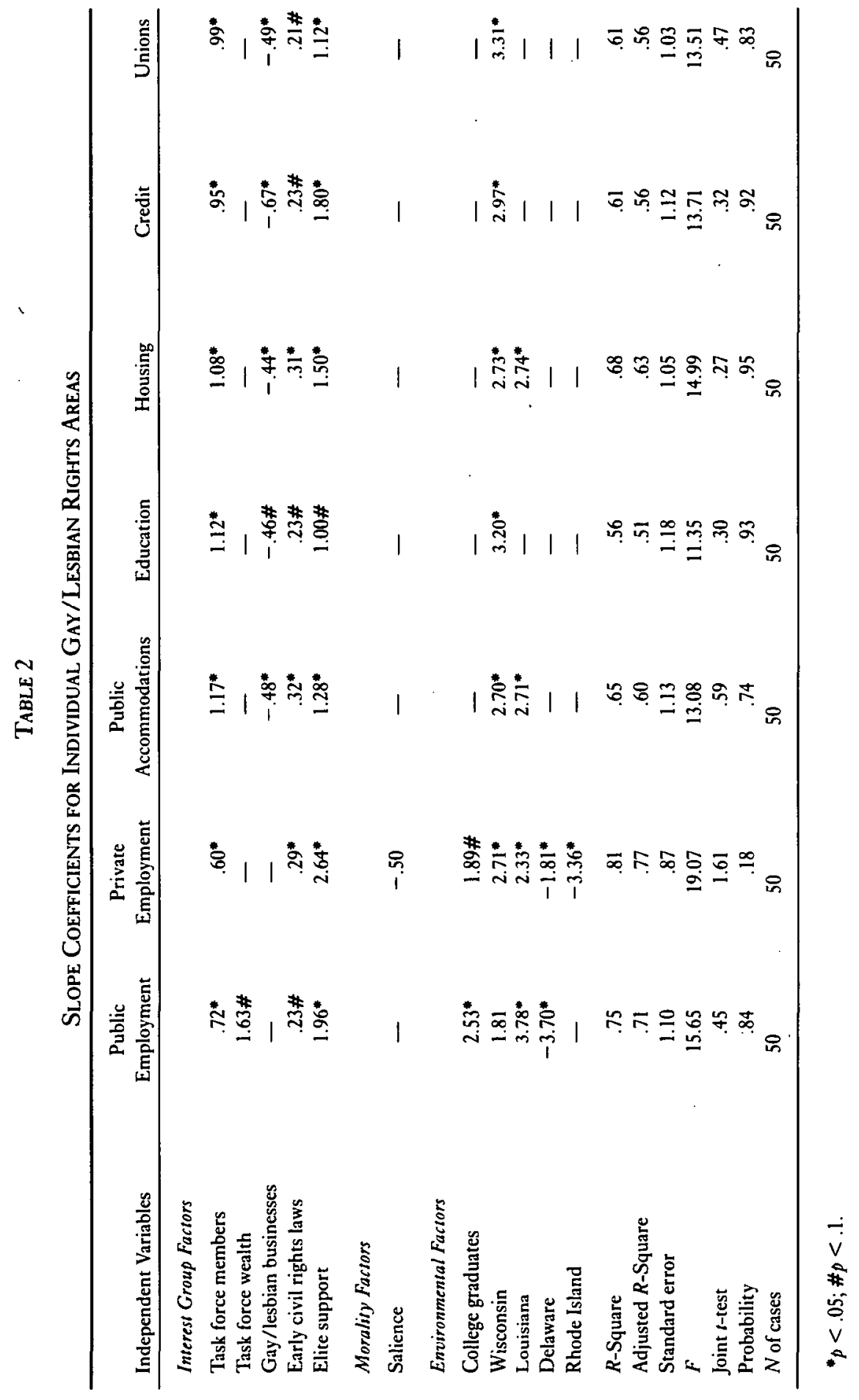


in the predicted direction in all seven cases. Task Force resources and college graduates remain in only a few of the equations, those dealing with discrimination in employment.

For the first time a morality politics variable stays in an equation. As salience increases, states are less likely to have policies that prevent discrimination in private employment. Since this is a single case, however, and the joint $f$-tests imply that none of the other morality politics variables adds any predictive power, this could be thought of as an anomaly except for one other set of results. In five of the seven cases, the number of gay-owned businesses remains in the equation; however, the relationship is negative rather than positive. Perhaps this measure also picks up the salience of gay and lesbian rights (the correlation between the two measures is .52). Gay-owned businesses mean that the gay community is open and visible; as a result, gay and lesbian issues could well be more salient either because gays and lesbians are more aggressive in seeking protection from discrimination or because opponents respond to openness by mobilizing. Salience and its impact on gay and lesbian politics merits further analysis. ${ }^{15}$

\section{Gay and Lesbian Politics Under Salient Conditions}

Thus far, our analysis has shown that gay and lesbian politics resembles interest group politics rather than morality politics. Our models suggested this was possible if the level of salience could be kept low; in fact, salience was negatively related to the adoption of some antidiscrimination policies. To verify our general framework, however, we need to examine gay and lesbian politics when they are salient to see if morality forces then become important. Our test cases for this are the 1992 state-wide initiatives held in Oregon and Colorado. In both cases, groups opposed to gay rights put initiatives on the ballot that would have prohibited the state or any community from passing legislation to protect individuals based on sexual orientation. These referenda were hotly contested, narrowly passing in Colorado and narrowly failing in Oregon. If our models' predictions are correct, county-level vote totals in Colorado and Oregon should be predicted well by morality variables but not predicted well by interest group variables. Our dependent variable is the percentage of the county vote that supported the pro-gay rights position.

By moving our unit of analysis from states to counties, we eliminate many of our variables that cannot be measured at the county level. Fortunately, most of these variables are interest group variables, and we seek to test the efficacy of the morality politics variables. Only two interest group variables are available-elite support ${ }^{16}$ and race, the latter being a surrogate for support for civil rights. The available

\footnotetext{
${ }^{15}$ In Haider-Markel and Meier (1995), we examine the unit effects in these equations. We provide a case study of Wisconsin (consistently the largest outlier) that demonstrates similar interest group variables affect the process in Wisconsin.

${ }^{16}$ The elite measure is available by congressional district so the measures here are for a county's congressional district.
} 
morality variables include percent Catholic, percent Protestant Fundamentalist, Democratic registration, party competition, and voter turnout (a salience measure) in the initiative election itself. Two environmental variables-percent of college graduates and urbanism-are also included.

Since Colorado and Oregon are different states, we should expect the political process to differ somewhat in the two states. Oregon is more homogeneous than Colorado ${ }^{17}$ and had only one-third the antidiscrimination coverage that Colorado did. Of the two, Oregon voted on the more extreme measure; in addition to banning antidiscrimination laws, it declared homosexuality "abnormal, wrong, unnatural, and perverse" and required schools to teach that it was so. In Oregon, the referenda was opposed by most political elites including Governor Barbara Roberts and presidential candidate Bill Clinton (Mahtesian 1993, 40; Barone and Ujifusa 1993, 1054). The Colorado initiative, sponsored by Colorado Family Values, faced a divided political elite with former U.S. Senator William Armstrong and University of Colorado football coach Bill McCartney publicly supporting the restrictions. In both states, Pat Robertson's Christian Coalition was active. To facilitate comparison, we estimated models for both states but included in both models any variable that mattered in either state. ${ }^{18}$ The results are in table 3.

The first two columns in table 3 confirm the morality politics pattern. In Colorado significant factors include Protestant Fundamentalists, partisanship, party competition, and turnout (all morality politics variables). In Oregon, significant morality factors are Protestant Fundamentalists and party competition (although the later is incorrectly signed). The only interest group factor in either state is a modest positive relationship with elite support in Colorado. ${ }^{19}$ Of particular interest is the strong relationship for college graduates. Its appearance can be tied to either morality or interest group politics. The overall pattern of morality politics is also supported by the high level of prediction ( $87 \%$ and $91 \%)$. Even if we have biased the results by not having many interest group measures, those measures would have little variance left to explain in the election outcomes.

Using party registration figures to represent partisanship is problematic. Party registration figures can lag several years behind voting patterns and, in both states, do not account for the independents that can control the balance of the vote. A more accurate representation of partisanship with links to the gay and lesbian

\footnotetext{
${ }^{17}$ For all the independent variables, Colorado had a much larger standard deviation than did Oregon, sometimes five times as large. Colorado has a larger nonwhite population, and the counties there also had a much larger range in terms of voting outcomes on the initiative.

${ }^{18}$ To produce a regression that reflects the population of the state as much as possible, we used weighted least squares with the number of registered voters as the weight. This prevents small rural counties from influencing the results disproportionate to their impact on the election.

${ }^{19}$ This relationship makes sense. Where political elites are all on one side of the issue as in Oregon, a measure of elite support should not have any predictive ability. Only when there is elite division should elite values matter.
} 
TABLE 3

Determinants of Percent Referenda Votes in Favor of Gay Rights

\begin{tabular}{lcccc}
\hline Independent Variable & $\begin{array}{c}\text { Colorado } \\
\text { Slope }\end{array}$ & $\begin{array}{c}\text { Oregon } \\
\text { Slope }\end{array}$ & $\begin{array}{c}\text { Colorado } \\
\text { Slope }\end{array}$ & $\begin{array}{c}\text { Oregon } \\
\text { Slope }\end{array}$ \\
\hline Interest Group Politics Factors & & & & \\
Elite support & $.123^{*}$ & -.027 & $.090^{*}$ & -.008 \\
Morality Politics Factors & & & & \\
Protestant fundamentalists & $-.089 \#$ & $-.166^{*}$ & -.009 & $-.152^{*}$ \\
Party competition & $.244^{*}$ & $-.561^{*}$ & .062 & $-.418 \#$ \\
Democratic partisanship & $.246^{*}$ & .266 & $-.123 \#$ & $-.433 \#$ \\
Turnout & $-.480^{*}$ & .364 & $-.377^{*}$ & -.242 \\
Vote for Bush & $\mathrm{NA}$ & $\mathrm{NA}$ & $-.722^{*}$ & $-.941^{*}$ \\
Environmental Factors & & & & \\
College graduates & $.551^{*}$ & $1.025^{*}$ & $.388^{*}$ & $.747^{*}$ \\
$R$-square & .87 & .91 & .91 & .94 \\
Adjusted $R$-square & .86 & .90 & .90 & .93 \\
Standard error & 627.89 & 666.05 & 514.97 & 567.77 \\
$F$ & 62.86 & 51.72 & 84.14 & 62.71 \\
$N$ of cases & 63 & 36 & 63 & 36 \\
\hline
\end{tabular}

$" p<.05 ; \# p<.1$.

Equations estimated with weighted least squares weighted for registered voters.

rights issue might be the 1992 presidential vote. The Bush-Quayle campaign specifically stressed family values, attempting to attract the votes of one of the coalitions in the gay rights conflict. Colorado's advocacy group actually took the name Colorado Family Values; Oregon's group, the Oregon Citizen's Alliance, sought to take over the state's Republican party and later did so (Barone and Ujifusa 1993, 1054; Morrison 1992, 2682). To reflect these more recent forces, the third and fourth columns of table 3 add the Bush vote percentage of the equation.

The importance of the Bush vote is immediately apparent; even with the high initial level of prediction, adding the Bush vote to the equation significantly improved the overall $f$-score of the equation. The Bush vote becomes the single-most important predictor of the election results. At least in Colorado and Oregon, counties that supported the Bush candidacy with its family value appeals were also associated with opposition to gay and lesbian rights. ${ }^{20}$ The impact of the variable absorbs a great deal of the impact of the other morality forces such as Protestant

${ }^{20}$ The Democratic partisanship measure is negative in both equations. With the control for the Bush vote, this variable obviously taps Democratic registration that is distinct from the coalition that supported Clinton. This might be an indicator of conservative Democrats. The results are barely significant, however, and too much stock should not be placed in them. 
Fundamentalism and partisanship. The causal linkage here (that is, did the Bush campaign mobilize the anticoalition or did the coalition members merely find the Bush candidacy compatible with their own interests) can not be disentangled with the present data. We can only conclude that partisanship as evinced by a presidential campaign that stressed morality was a strong predictor of votes against gay and lesbian rights. ${ }^{21}$

\section{CONCLUSION}

This study identified two models of politics that might describe gay and lesbian politics in the United States. In the morality politics model, policy is a function of religious forces, party competition, partisanship, high salience, and possibly education. In the interest group model, policy is determined by interest group resources along with supportive elite attitudes, prior public policies, and perhaps education. If policies are salient, then morality politics should result. If policies are not salient and the scope of the conflict is limited, then interest group politics should occur.

The empirical study found exactly that pattern. For the adoption of state and local policies to prohibit discrimination against gays and lesbians, the important variables were interest group resources, elite values, and past public policies. When individuals opposed to gay and lesbian rights, however, were able to expand the scope of the conflict by placing such issues on an election ballot, the political pattern resembled morality politics. The important factors were religion, party competition, partisanship, and education. The best measure of partisanship was the vote for President George Bush in 1992, a candidate who stressed family values, a political code word that rejects gay and lesbian life-styles, among others.

Our analysis, therefore, found that gay and lesbian politics is no different from politics in many other areas. If the scope of the conflict can be kept narrow, then interest group pressures can prevail if elite attitudes are supportive. When the scope of the conflict expands, then a broad-based form of morality politics exists where political power is demonstrated at the ballot box. Defining the scope of the conflict does not always guarantee who wins such issues, but defining the scope of the conflict determines what resources are important and advantages some coalitions have over others.

\section{Manuscript submitted 10 February 1995}

Final manuscript received 26 June 1995

\footnotetext{
${ }^{21}$ Expanding the scope of the conflict can have consequences that are unanticipated by the coalition seeking the expansion. By making gay rights a salient issue, the campaigns can also politicize gays and lesbians so they become more active. Before the referenda, Oregon had no openly gay/lesbian legislators. Since then four openly gay/lesbian legislators have been elected, more than any other state legislature (numbers reported by Patrick Cox of Oregon Public Radio, on All Things Considered [National Public Radio, Sept. 7, 1994, evening edition]).
} 


\begin{tabular}{lll} 
& \multicolumn{2}{c}{ APPENDIX } \\
Measure & \multicolumn{1}{c}{ Year } & \multicolumn{1}{c}{ Source } \\
\hline State, county local laws & 1993 & NGLTF Policy Institute 1993 \\
Population & 1990 & U.S. Bureau of the Census 1992 \\
Interest group size & 1992 & Provided directly by NGLTF \\
Interest group wealth & 1992 & Provided directly by NGLTF \\
Gay bars, businesses, etc. & 1992 & Damron Road Atlas 3rd ed. \& Odysseus 1992 \\
Litigation & $1976-1994$ & The Lambda Update \\
Elite values & $1987-1992$ & NGLTF Policy Institute 1993 \\
Civil rights laws & pre-1964 & McCrone and Cnudde 1968 \\
Percent Catholic \& & 1990 & Bradley et al. 1992 \\
$\quad$ Protestant fundamentalist & & \\
Party competition & 1986 & Holbrook and Van Dunk 1993 \\
Partisanship & 1990 & U.S. Bureau of the Census 1992 \\
Salience (articles) & $1985-1993$ & Nemsbank \\
Urbanism, education & 1990 & U.S. Bureau of the Census 1992 \\
Colorado/Oregon data on & 1992 & Secretary of State of each state \\
$\quad$ votes, registration & & \\
Colorado/Oregon religion & 1990 & Bradley et al. 1992 \\
Other Colorado/Oregon data & 1990 & 1990 Census \\
\hline
\end{tabular}

\section{REFERENCES}

Barone, Michael, and Grant Ujifusa. 1993. The Almanac of American Politics 1994. Washington, DC: National Journal.

Becker, Howard S. 1963. Outsiders: Studies in the Sociology of Deviance. New York: Free Press.

Blasius, Mark. 1994. Gay and Lesbian Politics. Philadelphia: Temple University Press.

Bradley, Martin B., Norman M. Green, Dale E. Johnson, Mac Lynn, and Lou McNeil. 1992. Churches and Church Membership in the United States, 1990. Atlanta: Glenmary Research Center.

Browne, William P. 1988. Private Interests, Public Policy, and American Agriculture. Lawrence: University Press of Kansas.

Carmines, Edward G., and James Stimson. 1980. "The Two Faces of Issue Voting." American Political Science Review 74:78-91.

Cohan, A. S. 1982. "Obstacles to Equality: Government Responses to the Gay Rights Movement in the United States." Political Studies 30:59-76.

Colby, David C., and David G. Baker. 1988. "State Policy Responses to the AIDS Epidemic." Publius 18:113-30.

D'Emilio, John. 1983. Sexual Politics, Sexual Communities. Chicago: University of Chicago Press.

Gibson, James L. 1987. "Homosexuals and the Ku Klux Klan: A Contextual Analysis of Political Tolerance." Western Political Quarterly 40:427-48.

Goggin, Malcolm. 1993. Understanding the Nem Politics of Abortion. Newbury Park, CA: Sage.

Gonsiorek, John C., and James D. Weinrich, eds. 1991. Homosexuality: Research Implications for Public Policy. Newbury Park, CA: Sage.

Gormley, William T. 1986. "Regulatory Issue Networks in a Federal System." Polity 18: 595-620.

Gusfield, Joseph R. 1963. Symbolic Crusade: Status Politics and the American Temperance Movement. Urbana: University of Illinois Press.

Haider-Markel, Donald P., and Kenneth J. Meier. 1995. "The Politics of Gay and Lesbian Rights." Presented at the annual meeting of the Midwest Political Science Association, Chicago. 
Hamilton, Lawrence C. 1992. Regression with Graphics. Pacific Grove, CA: Brooks/Cole.

Harry, Joseph. 1993. "Being Out: A General Model." Fournal of Homosexuality 26:25-39.

Himmelstein, Jerome L. 1983. The Strange Career of Marihuana. Westport, CT: Greenwood Press.

Hofferbert, Richard I., and John K. Urice. 1985. "Small Scale Policy: The Federal Stimulus Versus Competing Explanations for State Funding of the Arts." American Fournal of Political Science 29: 308-29.

Holbrook, Thomas M., and Emily Van Dunk. 1993. "Electoral Competition in the American States." American Political Science Reviem 87:955-62.

Holbrook, Thomas M., and Stephen L. Percy. 1992. "Exploring Variations in State Laws Providing Protections for Persons with Disabilities." Western Political Quarterly 45:201-20.

Holbrook-Provow, Thomas M., and Steven C. Poe. 1987. "Measuring State Political Ideology." American Politics Quarterly 15:399-416.

Key, V. O. 1964. Politics, Parties and Pressure Groups. 5th ed. New York: Thomas Y. Crowell.

Lowi, Theodore. 1969. The End of Liberalism. New York: Norton.

Luker, Kristin. 1984. Abortion and the Politics of Motherhood. Berkeley: University of California Press.

Luttbeg, Norman, and Harmon Zeigler. 1966. "Attitude Consensus and Conflict in an Interest Group." American Political Science Review 60:655-65.

Mahtesian, Charles. 1993. "Boycott Madness." Governing 7:36-40.

McCrone, Donald J., and Charles F. Cnudde. 1968. "On Measuring Public Policy." In State Politics, ed. Robert E. Crew Jr. Belmont, CA: Wadsworth.

Meier, Kenneth J. 1987. "The Political Economy of Consumer Protection." Western Political Quarterly 40:343-60.

Meier, Kenneth J. 1994. The Politics of Sin: Drugs, Alcohol and Public Policy. Armonk, NY: Sharpe.

Morgan, David R., and Kenncth J. Meier. 1980. "Politics and Morality." Social Science Quarterly $61: 144-48$.

Morrison, David C. 1992. "Why Gay Americans May Matter More." National Journal 24:2682.

National Gay and Lesbian Task Force Policy Institute. 1993. Gay and Lesbian Rights in the U.S. Washington, DC: author.

Nice, David C. 1988. "State Deregulation of Intimate Behavior." Social Science Quarterly 69:203-11.

Ringquist, Evan J. 1993. Environmental Protection at the State Level. Armonk, NY: Sharpe.

Ripley, Randall B., and Grace A. Franklin. 1991. Congress, the Bureaucracy, and Pubic Policy. Homewood, IL: Dorsey.

Sabatier, Paul A. 1988. "An Advocacy Coalition Framework of Policy Change and the Role of PolicyOriented Learning Therein." Policy Sciences 21:129-68.

Sabatier, Paul A., and Susan M. McLaughlin. 1990. "Belief Congruence between Interest-Group Leaders and Members." Journal of Politics 52:914-38.

Savage, Robert. 1978. "Policy Innovativness as a Trait of American States." Journal of Politics 40: 212-28.

Schattschneider, E. E. 1960. The Semi-Sovereign People. New York: Holt, Reinhart, and Winston.

Seltzer, Richard. 1993. "AIDS, Homosexuality, Public Opinion, and Changing Correlates Over Time." Fournal of Homosexuality 26:85-97.

Sniderman, Paul M., Barbara Kaye Wolfinger, Diana C. Mutz, and James E. Wiley. 1991. "Values Under Pressure: AIDS and Civil Liberties." In Reasoning and Choice, ed. Paul M. Sniderman, Richard A. Brody, and Philip E. Tetlock. Cambridge, MA: Cambridge University Press.

Stewart, Joseph, and James F. Sheffield. 1987. “Does Interest Group Litigation Matter?” fournal of Politics 49:780-98.

Sullivan, John L., James E. Piereson, and George E. Marcus. 1982. Political Tolerance and American Democracy. Chicago: University of Chicago Press.

Thomas, Clive S., and Ronald J. Hrebenar. 1992. "Changing Patterns of Interest Group Activity." In The Politics of Interest Groups, ed. Mark P. Petracca. Boulder: Westview. 
Tufte, Edward R. 1979. Data Analysis for Politics and Policy. Englewood Cliffs, NJ: Prentice-Hall.

U.S. Bureau of the Census. 1992. Statistical Abstract of the United States: 1992. 112th ed. Washington, DC: author.

Wald, Kenneth D., James W. Button, and Barbara Rienzo. 1996. "The Politics of Gay Rights in American Communities." American Journal of Political Science 40.

Wilson, Thomas C. 1995. "Urbanism and Unconventionality: The Case of Sexual Behavior." Sorial Science Quarterly 76:346-63.

Woodward, Kenneth L. 1993. "The Rites of Americans." Newsweek, November 29, p. 81.

Donald P. Haider-Markel is Ph.D. candidate in political science, University of Wisconsin, Milwaukee; Milwaukee, WI 53201-0413.

Kenneth J. Meier is professor of political science, University of Wisconsin, Milwaukee; Milwaukee, Wisconsin 53201-0413. 